\title{
Studenter presenterer bacheloroppgaven på poster
}

Høgskulen på Vestlandet har hatt posterutstilling av studen tenes bacheloroppgaver de siste to årene. Prosjektet var lærerikt, både sykepleiefaglig og metodisk.

\section{Forfattere}

\author{
Gjertrud Husøy \\ Førstelektor \\ Høgskulen på Vestlandet \\ Magda Buchvold \\ Høgskulelærar \\ Høgskulen på Vestlandet
}

\section{Nøkkelord}

Kunnskapsbasert sykepleie Undervisning Poster Studenter

Høgskulen på Vestlandet har hatt et prosjekt der noen studenter presenterte sine bacheloroppgaver i form av en poster. I to år har det vært posterutstilling i høyskolens foajé. Både studenter, lærere og gjester ved høyskolen har hatt anledning til å se alle posterne studentene har laget. Det har vært til stor inspirasjon for studentene å få se de forskjellige posterne. De studentene som har laget poster, syntes det var lærerikt og givende.

Å arbeide kunnskapsbasert er å anvende tre kunnskapsformer sammen i en bestemt kontekst (1). Pasientens og eventuelt pårørendes kunnskaper skal stå i sentrum. For sykepleieren og studenten kan den erfaringsbaserte kunnskapen utvikles gjennom selvevaluering, veiledning og refleksjon. Den forskningsbaserte kunnskapen må imidlertid finnes ved litteratursøk.

\section{Bakgrunn for prosjektet}

Faglærere ved Høgskulen Stord/Haugesund, nå Høgskulen på Vestlandet, hadde et tett samarbeid med en kirurgisk avdeling der studentene hadde praksis. Hensikten med samarbeidet var at praksisen skulle være en del av kunnskapsutviklingen mens studentene arbeidet med bacheloroppgaven.

I 2014 ble det satt i gang et prosjekt der noen studenter skulle presentere sine bacheloroppgaver til sykepleierne i avdelingen i form av en poster samt gi en muntlig presentasjon. Det at studentene kunne utvikle en poster som var basert på bacheloroppgaven, skulle integrere den kunnskapsbaserte arbeidsprosessen som metode i studentenes praksisstudier (2).

I 2016 hadde posterprosjektet foregått i to år. Prosjektet er forankret i rammeplanen for sykepleierutdanningen. Der står det at formålet med sykepleierutdanningen er å «utdanne yrkesutøvere som er kvalifisert for sykepleiefaglig arbeid i alle ledd av helsetjenesten, i og utenfor institusjoner» (3, s. 4).

\section{Studiekrav}

På forhånd hadde studentene hatt en kunnskapsbasert praksisoppgave (KBP) der studentene valgte tema innen sårproblematikk, smertelindring, ernæring eller hygiene. I studiekravet sto følgende: 
«Oppgaven skal være forankret i sykepleiefagets pensumlitteratur/artikler som er relevant for aktuelle praksissted (sykehjem, hjemmesykepleie, medisin, kirurgi eller psykiatri) og valgte problemstilling. Dette danner grunnlaget for å utøve sykepleie i tråd med sykepleiens vitenskapelige grunnlag, som igjen skal bidra til faglig forsvarlig sykepleie, med fokus på forebygging av komplikasjoner og ivaretakelse av pasientens sikkerhet i tråd med oppdatert kunnskap. I faglig forsvarlig sykepleie er dessuten evne til kritisk refleksjon og justering av fagutøvelsen helt sentralt.» (4)

\section{Utvikling av poster}

Prosjektet med å lage poster basert på en praksisnær bacheloroppgave er en videreutvikling av forprosjektet «Kunnskapsbasert praksis i sykehus» (2). Posterprosjektet viser en sammenhengende kjede fra kunnskapsbasert praksisoppgave til bacheloroppgave, og videre til posteren.

Ut fra studiekravet kan vi lese at studentene som er i klinisk praksis, skal skrive en KBP-oppgave om en situasjon de har erfart i praksis. Studentene må prioritere hva de ønsker å finne ut av, lære mer om og få oppdatert kunnskap om. Oppgaven er individorientert, men har overordnet oppmerksomhet på sykepleie til grupper, rutiner, prosedyrer med mer.

\section{Gjennomføring og metode}

Da posterprosjektet ble satt i gang i 2014, var det 21 studenter som fikk anledning til å lage poster.

\section{«I 2016 kunne samtlige studenter melde seg på, og totalt 27 studenter ble med.»}

I 2016 kunne samtlige studenter melde seg på, og totalt 27 studenter ble med. Denne gangen fikk alle praksisveilederne undervisning før de skulle veilede studentene. På forhånd hadde både lærere og studenter hatt anledning til å se posterutstillingen fra året før. Det var til god hjelp og inspirasjon for begge partene.

\section{Valg av tema}

Da studentene skulle velge tema og problemstilling for bacheloroppgaven, viste det seg at flere tok utgangspunkt i den kunnskapsbaserte praksisoppgaven (KBP) de hadde hatt i den foregående praksisen. Noen studenter valgte problemstillinger gitt av kirurgisk avdeling som praksisfeltet hadde meldt inn som et behovsområde, eksempelvis sårbehandling eller forebygging av trykksår.

For å belyse temaet må studentene innhente aktuell forskning fra godkjente databaser. Her er ikke Google, Kvasir og liknende søkemotorer gode nok. Studentene bruker forskningsartikler og erfaringskunnskap og anvender alle trinn i en KBP-oppgave.

I praksis fokuserer studentene på å anvende alle de seks trinnene i den kunnskapsbaserte arbeidsprosessen (1):

- reflektere i fagutøvelsen og erkjenne behov for ny kunnskap

- formulere spørsmål

- gjennomføre kunnskapssøk

- kritisk vurdere kunnskap

- anvende kunnskapen

- evaluere

Denne prosessen er et læringsredskap for å integrere bruken av forskningsbasert kunnskap, erfaringsbasert kunnskap og pasientkunnskap når sykepleie utøves. I tillegg tar studentene utgangspunkt i anbefalte verktøy for kvalitetsforbedring (5).

Selve oppgaven skal være forankret i den pensumlitteraturen for sykepleiefaget som er relevant for det aktuelle praksisstedet, som for eksempel relatert til sykehjem, hjemmesykepleie, medisin, kirurgi eller psykiatri, samt den valgte problemstillingen. 
Kunnskap fra pensum danner grunnlaget for å utøve sykepleie i tråd med sykepleiens vitenskapelige grunnlag. Målet er å forebygge komplikasjoner og ivareta pasientens sikkerhet i tråd med oppdatert kunnskap. Her er sykepleiestudentens evne til kritisk refleksjon og justering av fagutøvelsen helt sentral.

\section{Praksiserfaring}

I forprosjektets sluttrapport «Kunnskapsbasert praksis i sykehus» (2) kom det frem at studentene delte opplevelser og hendelser om erfaringsbasert kunnskap mens de var i praksis. De viste at de hadde kunnskap fra lærebøkene i tankene når de utøvde kirurgisk sykepleie. Det kom også frem at studentene som var med i forprosjektet, hadde søkt etter forskningsbasert kunnskap ganske ofte (2).

\section{Eksempler på poster}

Det er en kunst å komprimere teksten og lage en layout som både vekker interesse og formidler budskapet. Det er lett å gå forbi en poster full av tekst. Studentene hadde på forhånd fått vite at innholdet på den faglige posteren skulle bygges opp etter IMRADprinsippet (innledning, metode, resultat og drøfting).

\section{三 «Det er lett å gå forbi en poster full av tekst.»}

Posteren skal også påføres forfatternes navn og en kontaktadresse, gjerne epostadressen til en kontaktperson. Et talende bilde må gjerne være med som blikkfang. Ut fra disse kriteriene ble posterne vurdert etter både form og innhold. Studentene hadde fått se følgende eksempler på hvordan en plakat kunne utformes (figur 1 og 2). 


\section{TITTEL \\ Studentens navn}

HøGSKOLEN STORD/HAUGESUND

Avdeling for helsefag, bachelorutdanning i sykepleie, Stord

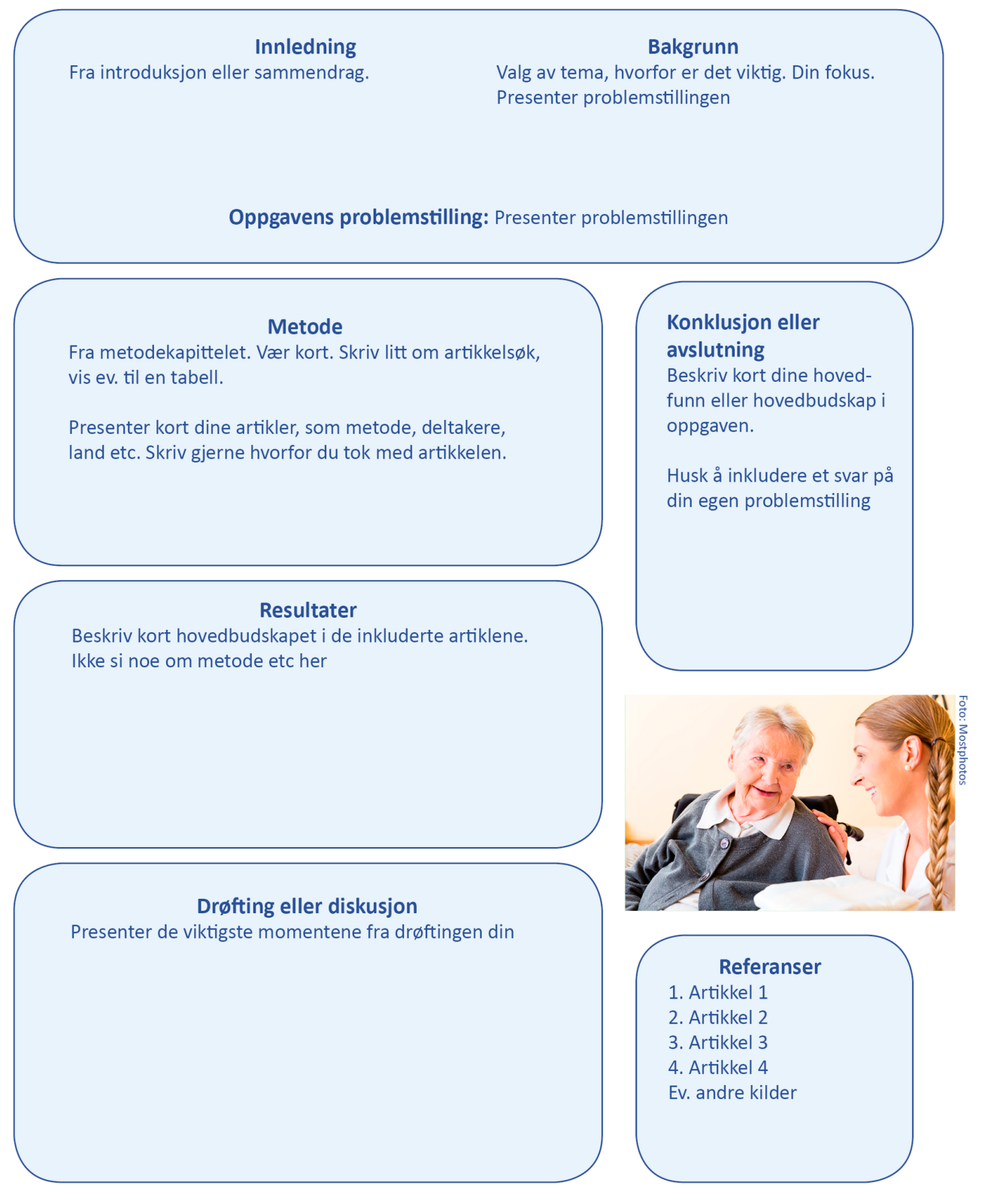




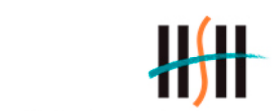

HøGSKOLEN STORD/HAUGESUND

\section{TITTEL}

Studentens navn

Avdeling for helsefag, bachelorutdanning i sykepleie, Stord

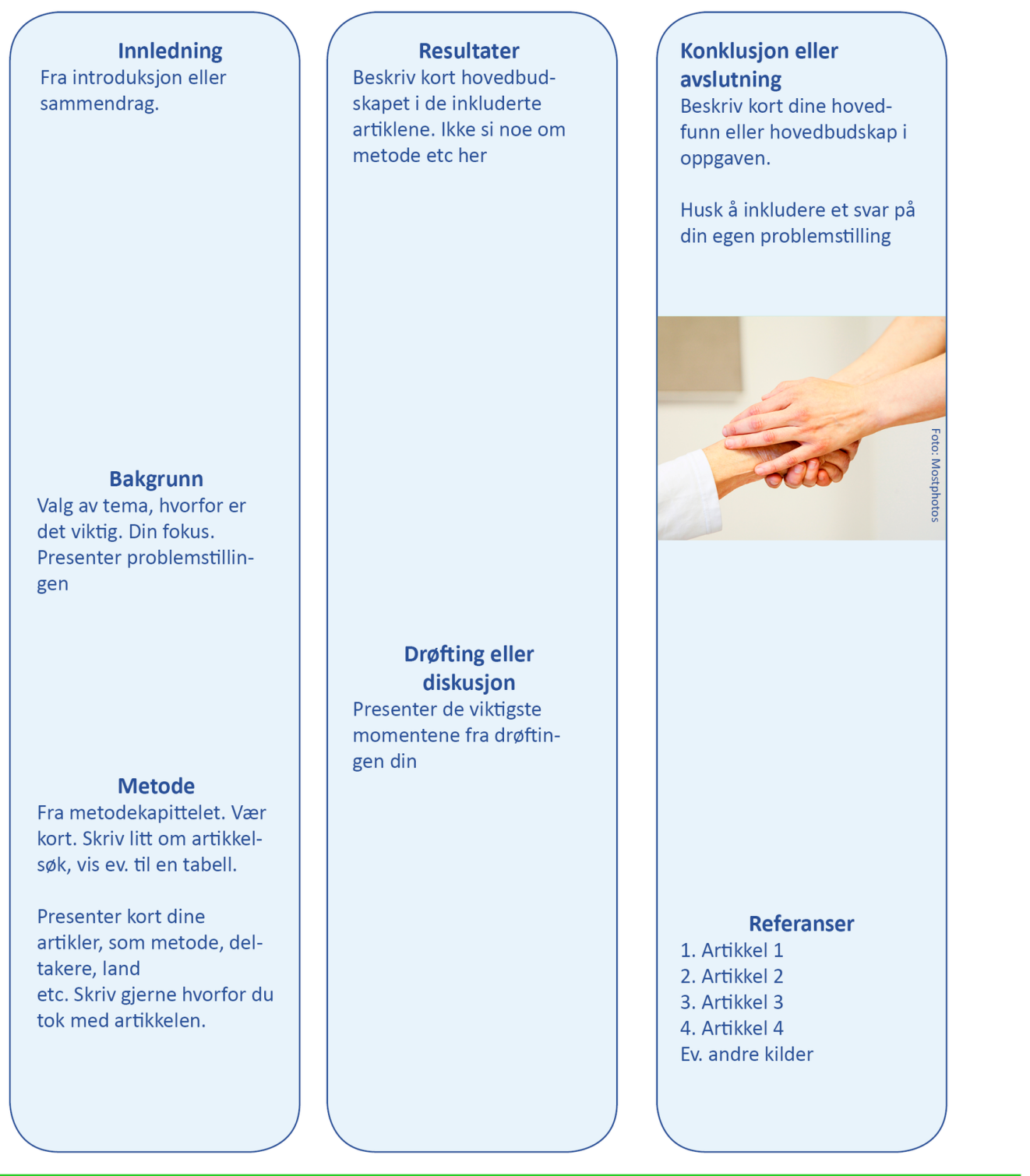

Det var opp til studentene å bestemme form og fargevalg på de ulike delene av posteren. Som i all akademisk praksis skulle kildene oppgis, både til tekst og bilde. Studentene hadde blitt opplyst om at de måtte anonymisere bilder og henvisninger til pasientsituasjoner. De måtte ikke gi opplysninger som kunne gjenkjenne personer eller informasjon som var av sensitiv karakter for involverte personer.

\section{Kunnskap til praksis}

Etter at studentene hadde levert inn bacheloroppgaven, gikk de ut i ny praksis. Tanken med prosjektet var at studentene skulle levere oppdatert kunnskap tilbake til avdelingen. Prosjektets styrke viste seg å være studentenes kunnskap om KBP og artikkelsøk. Det var viktig for kunnskapsutviklingen i praksis, da mange av de ansatte ikke hadde samme kunnskap om KBP og artikkelsøk (2). 
Videre kom det frem at de involverte viste engasjement og vurderte prosjektet som spennende, krevende, utfordrende og lærerikt. I tillegg må samarbeidet mellom høyskole eller universitet og sykehus ivaretas for å utvikle kunnskapsbasert sykepleie i praksis, og videreutvikles for kommende kull.

Det er imidlertid et spenningsfelt mellom en KBP-oppgave og en bacheloroppgave, der bacheloroppgaven tradisjonelt har fokusert på ulike pasientsituasjoner på individnivå. I en posteroppgave fokuseres det mer på tema innen en erfart situasjon i praksis.

\section{Tilbud til alle}

I to år har vi hatt posterutstilling i høyskolens foajé. Både studenter, lærere og gjester ved høyskolen har hatt anledning til å se alle de flotte posterne studentene har laget. $\AA$ få se eksempel på en poster er til stor inspirasjon og gir ideer til hva studentene selv skal legge vekt på. De studentene som har laget poster, har syntes det var givende.

Alle som kunne, har presentert posterne sine til praksisfeltet. De studentene dette var upraktisk for, presenterte posteren i studentgruppen etterpå. Studentene fremhevet at det å få dele erfaring og kunnskap var svært viktig og lærerikt for å kunne forstå og utføre god sykepleie.

\section{三 «Prosjektet viser et klart læringsutbytte for studentene.»}

Posterutstillingen på høyskolen er nå en del av undervisningen til alle sykepleierstudentene i kullet. Suksessen ved kirurgisk avdeling førte til at alle på kullet nå får tilbud om å lage poster i stedet for en annen oppgave i praksis. Det har vært både utfordrende og lærerikt å utvikle en poster, for studenter så vel som lærere.

Prosjektet viser et klart læringsutbytte for studentene. Nye erfaringer og nye problemstillinger i fremtiden vil komme, og disse erfaringene vil være med på å modne studentene og hjelpe fremtidige sykepleiere til å arbeide kunnskapsbasert.

\section{Referanser}

1. Nortvedt MW, Jamtvedt G, Graverholt B, Nordheim LV, Reinar LM. Å arbeide og undervise kunnskapsbasert - en arbeidsbok for sykepleiere. Oslo: Akribe; 2012.

2. Buchvold MV, Huser B, Kannelønning H. Sluttrapport: Kunnskapsbasert praksis i sykehus. Praksisutviklingsprosjekt ved Stord Sykehus, Helse Fonna og Høgskolen Stord/Haugesund, avdeling Stord; 2012.

3. Kunnskapsdepartementet. Rammeplan for sykepleieutdanningen. Oslo: Kunnskapsdepartementet; 2008.

4. Rykkje L. Pilotprosjekt: Lage poster av bacheloroppgava. Stord: Høgskolen Stord/Haugesund; 2014.

5. Helsebiblioteket. Om kunnskapsbasert praksis som kvalitetsforbedring.

Tilgjengelig fra:

http://www.helsebiblioteket.no/Kvalitetsforbedring/Kunnskapsbasert+praksis/Forsideartikkel+Kunnskapsba/Om+kunnskapsbasert+praksis+s (nedlastet 05.03.2018). 